ЗНАЊЕ, СТАВОВИ И ПРАКСА РОДИТЕЉА И ПЕДИЈАТАРА У ВЕЗИ СА ИМУНИЗАЦИЈОМ - КРАЉЕВО, РАШКА, ВРЊАЧКА БАЫА

Верица Ђукић ${ }^{1}$, Владан Шапоњић ${ }^{2}$, Надица Радоњић ${ }^{3}$, Златана Марковић ${ }^{4}$, Љиљана Филиповић ${ }^{5}$

\title{
KNOWLEDGE, ATTITUDE AND PRACTICE ABOUT IMMUNIZATIONS OF PARENTS AND PEDIATRICIANS - KRALJEVO, RASKA, VRNJACKA BANJA
}

Verica Djukic, Vladan Saponjic, Nadica Radonjic, Zlatana Markovic, Ljiljana Filipovic

\section{Сажетак}

Због пада обухвата појединим вакцинама и расправе о вакцинацији која се води у јавности, одлучили смо се за спровођење истраживања са ииљем да се испитају знаъа, ставови и пракса родитеља и педијатара о овој теми. Истраживање је спроведено у Краљеву, Рашки и Врњачкој Бањи током новембра и децембра 2016. године.

Око 22\% анкетираних родитеља мисли да вакиине нису ефикасне у спречавању болести или није сигурно у њихов ефекат, а 43\% родитељь не зна против којих болести се дете вакиините. Најзначајнији извор информација за родитеље је педијатар, а затим интернет. Око 26\% родитеља сматра да су неке вакиине штетне, а 15,7\% да су неке и непотребне; 13\% сматра да вакцине нису довољно испитане, а половина сматра да постоји разлика у безбедности домаћих и увозних вакцина. Одлуку да престану да вакиинишу деиу донело је 1\% родитеља, а око 4\% се још увек двоумило у време истраживања.

И код педијатара смо утврдили да постоји одређени степен неповерења у вакцинацију. Један од анкетираних педијатара јасно износи негативан однос према имунизачији. Према резултатима истражива$ю$ юа, педијатри у својој каријери нису имали значајнијих нежељених догађаја у вези са имунизачијом.

\section{Summary}

Due to decreased immunization coverage and ongoing public discussions about vaccines, we have decided to conduct a survey on knowledge, attitude and practice among parents and pediatricians. The survey was conducted in Kraljevo, Raska and Vrnjacka Banja during November and December 2016.

About $22 \%$ of parents think that vaccines are not efficient in disease prevention or are not certain about effects, while 43\% do not know against what diseases children are immunized. The most important source of information for parents are pediatricians, followed by Internet. Around 26\% parents find some vaccines harmful and $15.7 \%$ think some of the vaccines are not needed. Some 13\% has an opinion that vaccines are not properly tested; while one half of parents are certain that there is a difference in safety between domestic and imported vaccines. The decision to stop vaccination of their children was made by $1 \%$ of parents, and additional $4 \%$ were still considering that option at the time of survey.

We have found that certain doubts about immunization are present in pediatricians, too. One of respondents in the survey expressed clearly negative attitude towards immunization. None of pediatricians have diagnosed serious adverse events following immunization during their carreer so far.

\footnotetext{
${ }^{1}$ Др Верица Ђукић, Центар за превенцију и контролу болести, Завод за јавно здравље Краљево, Србија.

2 Др Владан Шапоњић, Центар за превенцију и контролу болести, Завод за јавно здравље Краљево, Србија

${ }^{3}$ Др Надица Радоњић, Центар за превенцију и контролу болести, Завод за јавно здравље Краљево, Србија.

4 Златана Марковић, Центар за превенцију и контролу болести, Завод за јавно здравље Краљево, Србија.

5 Љиљана Филиповић, Центар за превенцију и контролу болести, Завод за јавно здравље Краљево, Србија.
} 
Добијени резултати указују на постојање озбиљног проблема са поверењем $у$ имунизаџију уопште, а за поједине вакцине чак у мери која угрожава колективни имунитет и представља ризик за појаву епидемија болести против којих се имунизачија спроводи.

Кључне речи: вакцине, имунизација, родитељ, педијатри, ставови.
The survey proved that there is a lack of trust in vaccines in general and that for some vaccines it impacts collective immunity to the level that enables outbreaks of vaccine preventable infections.

Key words: vaccines, immunization, parent, pediatricians, attitude.

\section{УВОД}

B ишегодишњи проблеми у спровођењу програма обавезних имунизација преносили су се из године у годину, а покушаји да се стање нормализује нису дали очекиване резултате, те се и даље за поједине вакцине не постиже задовољавајући обухват.

Део проблема настаје услед системских недостатака, као што су пропуштене прилике за имунизацију, поновљено позивање, услед привремених несташица појединих вакцина. Тако долази до тешкоћа у праћењу и контроли извршене имунизације, преношења невакцинисане деце из претходних година у планове за наредну годину и сличних административно-техничких проблема. Други део негативних фактора потиче из „парамедицинске сфере“, односно то је већ дуго присутна негативна кампања у јавности (посебно на интернету и друштвеним мрежама, у великој мери помогнута сензационалистичким медијским праћењем) која ствара неповерење код родитеља и дела стручне јавности и тиме битно омета спровођење програма имунизације. Ефекти имунизације се дугорочно компромитују и стварају се услови за поновно јављање болести против којих се врши вакцинација, па и у епидемијском облику, за шта постоје бројни примери. Истовремено, овакав обухват појединим вакцинама угрожава статус који је достигнут у ерадикацији дечје парализе и елиминацији болести попут малих богиња, тетануса, великог кашља, рубеоле, заушки, дифтерије, и то не само у Србији већ и у ширем региону.

Због свега наведеног желели смо да утврдимо какав је однос родитеља према вакцинацији и колики утицај тај однос има на пад обухвата који бележимо последњих година.

Величину узорка смо одредили користећи програм EpiInfo. Упитник је сачињен у Центру за превенцију и контролу болести Завода за јавно здравље Краљево и тестиран на малом узорку запослених који по карактеристикама припадају популацији планираној за испитивање (родитељи који имају децу узраста 19-59 месеци).

Упитник су родитељима делили запослени у Центру за превенцију и контролу болести у чекаоницама домова здравља Краљево, Рашка и Врњачка Бања.

Истовремено је сачињен и други упитник за педијатре истих домова здравља, у циљу сагледавања њихових ставова и праксе када је у питању имунизација.

\section{ЦИЉ РАДА}

Истраживање је спроведено са циљем да се сагледају знања, ставови и пракса родитеља и педијатара у вези са имунизацијом, а ради планирања даљих активности на унапређењу обухвата обавезном имунизацијом на подручју надлежности Завода за јавно здравље Краљево. 


\section{МАТЕРИЈАЛ И МЕТОДЕ}

Користећи искуства других сличних истраживања, сачинили смо посебне упитнике за родитеље и педијатре. Упитник је подељен свим педијатрима који су били присутни у време спровођења студије (26). Усвојено је да се у истраживање укључују родитељи деце старости 19-59 месеци (1,5 до 6 година). У Краљеву су добијена 242 попуњена упитника родитеља, у Врњачкој Бањи 53 и у Рашки 56 упитника (потребна величина узорка за родитеље је била 300 ).

Сви упитници су обрађени употребом Excel програма. За анализу резултата кори- шћене су просечне вредности, пропорције и поређење апсолутних вредности учесталости.

\section{РЕЗУЛТАТИ И ДИСКУСИЈА}

\section{РОДИТЕЉИ}

Упитнике су попуњавали родитељи или старатељи у чекаоницама амбуланти, односно саветовалишта. Преглед броја деце по годиштима дат је у табели. У неколико упитника (Краљево пет и Рашка два) није било наведено годиште деце.

Табела 1. Година рођења деце анкетиранх родитеља.

\begin{tabular}{|c|l|c|c|c|c|c|c|c|c|}
\hline \multirow{2}{*}{$\begin{array}{c}\text { Редни } \\
\text { број }\end{array}$} & \multirow{2}{*}{ Место } & \multicolumn{7}{|c|}{ Година } & \multirow{2}{*}{ Свега } \\
\cline { 3 - 11 } & 2009 & 2010. & 2011. & 2012. & 2013. & 2014. & 2015. & \\
\hline 0 & 1 & 2 & 3 & 4 & 5 & 6 & 7 & 8 & 9 \\
\hline 1 & Краљево & 2 & 15 & 46 & 57 & 42 & 44 & 31 & 237 \\
\hline 2 & Рашка & 0 & 17 & 6 & 7 & 7 & 10 & 7 & 54 \\
\hline 3 & $\begin{array}{l}\text { Врьач ка } \\
\text { Бања }\end{array}$ & 1 & 0 & 4 & 16 & 13 & 13 & 6 & 53 \\
\hline 4 & Укупно & 3 & 32 & 56 & 80 & 62 & 67 & 44 & 344 \\
\hline
\end{tabular}

За два упитника из Краљева није било могуће утврдити ко је од родитеља/старатеља попуњавао.

Просечна старост очева у испитивању је била у Краљеву 35,4 (интервал 22-70 година), у Рашки 35,3 (22-52) и у Врњачкој Бањи 36,5 (25-57) година. Просечна старост мајки је била у Краљеву 32,1 (21-48), Рашки 31,4 (23-42) и у Врњачкој Бањи 31,6 (22-43) година. Не постоје битне разлике у старости родитеља укључених у истраживање у три посматране општине.
Графикон 1. Анкетирани родитељи/ старатељи.

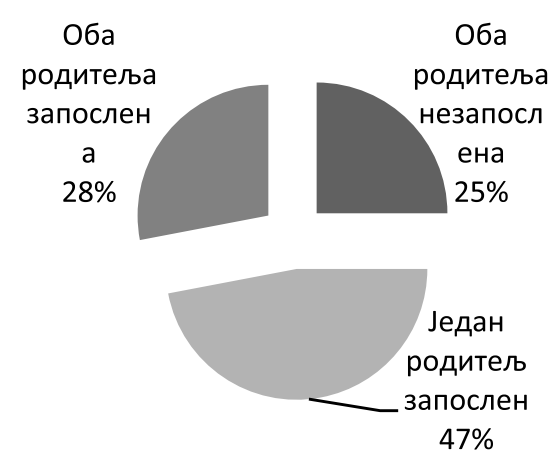

Више испитаника је из градског подручја (59\%), што је и очекивано, а међу општинама постоје мале разлике које није могуће валидно тумачити с обзиром на релативно велики проценат испитаника који није одговорио на ово питање. 
Графикон 2. Место становања родитеља.

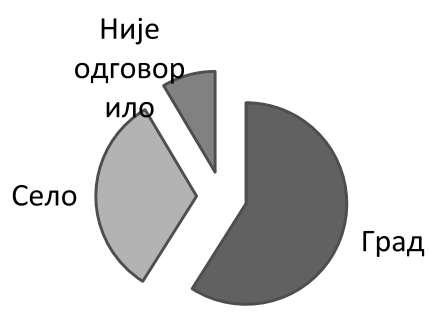

Просечан ниво образовања је сличан у све три општине - нешто виши од завршене средње школе, са малим учешћем особа са нижим нивоом образовања (мање од завршене средње школе), укупно 5,4\%.

Графикон 3. Ниво образовања родитеља.

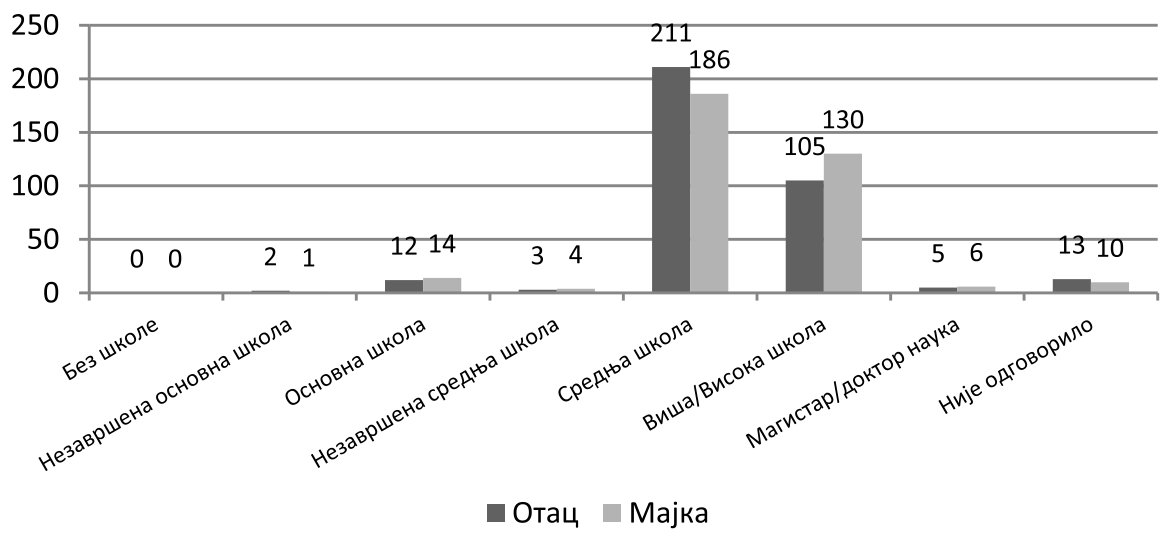

Кадапосматрамосоцијални статус (према утиску родитеља, без квантификовања), огромна већина је одговорила да свој социјални статус сматра просечним. У Краљеву подједнак број (по четири од укупно 184 испитаника који су одговорили на ово питање или по 2,2\%) свој статус је оценило нижим или вишим од просека. Међутим, у Рашки је свој социјални статус оценило као потпросечан $10 \%$ испитаника (5 од 48), а у Врњачкој Бањи 5\% (2 од 40), док нико у ове две општине није свој социјални статус оценио као натпросечан. Наравно, добијени резултати се морају узети са резервом јер није тражено даље појашњавање у смислу просечног дохотка по домаћинству, услова становања и слично, али ћемо покушати да упоредимо одговоре о имунизацији и са нивоом образовања и са социјалним статусом породица како бисмо сагледали да ли има потребе за додатним истраживањима и акцијама у том правцу.

Као један од индикатора социјалног статуса породица, посматрали смо запосленост родитеља и резултати су приказани на следећој слици.
Графикон 4. Запосленост анкетираних родитеља.

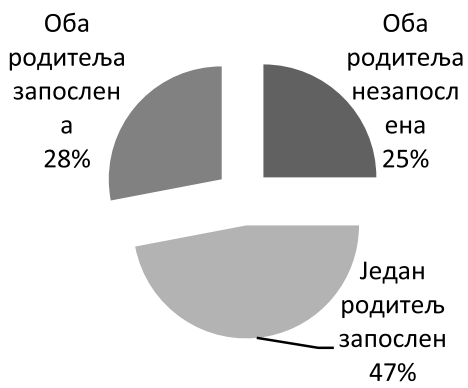

\section{Ставови}

На почетку упитника тражили смо од родитеља да изнесу своје мишљење о томе да ли су вакцине ефикасне у спречавању болести.

Разлике у одговорима у односу на социјални статус породице и место становања нису значајне. Уочава се већи степен неповерења према ефикасности вакцина код родитеља са нижим нивоом образовања (15\% неповерљивих према $3 \%$, односно 6\% са средњим и високим образовањем). 
Кад смо посматрали однос према поузданости вакцина, 69\% оних који сматрају да вакцине нису ефикасне истовремено има став и да оне нису испитане и поуздане, у односу на $9 \%$ оних родитеља које верују у ефикасност вакцина.

Међутим, када смо сагледали став родитеља према питању да ли постоји разлика у безбедности вакцина које се производе у Србији у односу на оне које се увозе, половина свих испитаника сматра да постоји. Очекивано, више их је међу и иначе неповерљивим родитељима $(75 \%)$, али и код родитеља који верују у ефикасност вакцина, 44\% мисли да су оне које се увозе непоуздане, односно небезбедне.

Више од четвртине свих родитеља који су одговорили на питање да ли сматрају да неке од вакцина могу нашкодити здрављу детета одговорили су да неке од вакцине могу бити и штетне за дете, а посебно је важно што проценат родитеља са таквим ставом расте са степеном образовања (код родитеља са високом или вишом школом $32,9 \%$, а код родитеља са основним или нижим образовањем $12,5 \%$ ).

Од 328 родитеља 55 или 16,8\% мисли да су неке вакцине непотребне. Међу њима је и 39 родитеља који истовремено имају став и да су неке вакцине небезбедне. Притом, веома мали број родитеља је и рекао које вакцине сматра непотребним (десет ММР, четири хепатитис Б, једна вакцина против туберкулозе, једна све ревакцине (поновно давање истих вакцина), док остали нису одговорили на то питање). Недостатак одговора на питање које вакцине сматрају непотребним је у корелацији са ниским нивоом знања о врстама вакцина у дечјем узрасту код родитеља.

У вези са разликом у броју вакцина које се дају деци у Србији у односу на друге европске земље, 226 родитеља је одговорило да не зна. Од оних који су изнели своје мишљење о том односу, 51 сматра да се код нас даје већи број вакцина, 47 исти број и 23 сматра да је у Србији број вакцина у дечјем узрасту мањи.

\section{Знање}

На постављено питање о болестима против којих се вакцинише одговорило је $2 / 3$ родитеља. Међу њима 26\% не зна ниједно обољење против ког се деца вакцинишу, а $43 \%$ зна да наведе једну до две болести, док само једна трећина зна три и више болести против којих се врши вакцинација.

Од родитеља који сматрају да знају довољно о вакцинацији, на питање о болестима против којих се врши вакцинација одговорило је 129 . Од тога 18 (14\%) не зна да наведе нити једну болест, 34 (26\%) зна једну до две, док 50 родитеља (39\%) на ово питање није ни одговорило.

Поузданост различитих извора информација родитељи сурангирали од 1 до5 (гдеје 1 најмање поуздан и 5 најпоузданији). Нема битне разлике у оцењивању поузданости различитих извора информација међу родитељима који сматрају да су довољно информисани о вакцинама и оних који сматрају да немају довољно информација. И једни и други као најпоузданији извор виде педијатра, па потом интернет.

Табела 2. Очена поузданости извора информација у односу на мишљење о степену сопствене информисаности о вакцинама.

\begin{tabular}{|c|c|c|c|c|c|c|}
\hline \multirow{2}{*}{$\begin{array}{l}\text { Р е дн и } \\
\text { број }\end{array}$} & $\begin{array}{l}\text { Да ли сматрате } \\
\text { да сте довољно } \\
\text { информисани о } \\
\text { вакцинама? }\end{array}$ & \multicolumn{5}{|c|}{ Просечна оцена поузданости извора информација } \\
\cline { 3 - 7 } & $\begin{array}{l}\text { Пријатељи/ } \\
\text { рођаци }\end{array}$ & $\begin{array}{l}\text { Телевизија/ } \\
\text { Штампа }\end{array}$ & Интернет & Педијатар & Друго \\
\hline 0 & 1 & 2 & 3 & 4 & 5 & 6 \\
\hline 1 & Да & 2,6 & 2,6 & 3,2 & 4,8 & 1,9 \\
\hline 2 & $\mathrm{He}$ & 2,8 & 2,7 & 3,3 & 4,4 & 1,8 \\
\hline
\end{tabular}




\section{Пракса}

Већина родитеља сматра да нису довољно информисани о вакцинама и $2 / 3$ њих тражи од педијатра додатне информације. Они који себе сматрају довољно информисанима у мањем проценту траже додатне информације - 55\%. Сличне резултате добијамо и на питање о другим лековима (осим вакцина) које прописују педијатри.

Пошто се последњих година много прича о негативним ставовима у вези са вакцинама, и о одбијању родитеља да вакцинишу своју децу, желели смо да проверимо да ли, када су други лекови у питању, постоји апсолутно поверење код родитеља и да ли у свим ситуацијама поступају према препоруци педијатра. Добили смо да је 14\% родитеља бар једном поступило супротно савету педијатра и одбило да свом детету да прописани лек.

Вакцинације су честа тема у приватним разговорима међу родитељима $(87 \%$ је одговорило позитивно на то питање), а чак $67 \%$ родитеља својим рођацима и пријатељима препоручује да вакцинишу децу кад разговарају о томе.

Највећи број родитеља обавештење о наредној вакцинацији добија приликом одласка код лекара због претходне дозе вакцине.

Долазак код педијатра није се увек завршавао вакцинацијом по плану, већ је 234 родитеља (70\%) имало једно или више искустава одлагања вакцинације иако је термин био заказан. Разлоге за одлагање вакцинације највећи број родитеља није навео, а од оних који су се изјаснили 56 je навело привремене контраиндикације (утврђене педијатријским прегледом), а седам родитеља је изјавило да у заказаном термину није било потребних вакцина.

По један родитељ је навео да не жели да вакцинише дете одређеним вакцинама, односно свим вакцинама.

Као резултат свих утицаја (закона, препорука лекара, на првом месту педијатра, медијских расправа, лажних вести, утицаја заједнице и других) родитељи доносе одлуку да ли ће вакцинисати своју децу у складу са програмом или не. У нашем узорку 330 родитеља (94\% свих анкетираних) изјавило је да ће наставити да води своју децу на вакцинације у складу са програмом. Четворо $(1,1 \%)$ је било изричито да неће више вакцинисати своју децу, док је 4\% родитеља (14 анкетираних) и даље неодлучно. Само троје (мање од 1\%) није дало одговор на ово питање.

\section{ПЕДИЈАТРИ}

У Дому здравља Краљево ради 19 специјалиста педијатрије и сви су попунили упитник. На дечјем одељењу краљевачке Опште болнице ради осам педијатара, од којих је једна на дужем одсуству. Упитник је попунило свих седам педијатара који су тренутно били присутни, те је укупно прикупљено 26 упитника (одзив 100\%).

У већини се ради о лекарима специјалистима млађе и средње генерације. До десет година специјалистичког стажа је девет лекара, од 11 до 20 година специјалистичког стажа има 11 лекара, док је са више од 20 година специјалистичког стажа шест.

На питање да ли мисле да знају довољно о вакцинама које примењују у својој пракси, два лекара нису одговорила, а троје се изјаснило негативно. Питање је са разлогом широко постављено, без прецизирања специфичних знања (врсте вакцина, начин производње, састав, имунолошки процеси након вакцинације, механизам настанка нежељених догађаја и сл.) са намером да се посредно испита да ли су бројне недоумице и гласине у вези имунизације које су се протеклих година јавиле у општој, али и стручној јавности, утицале на самопоуздање лекара који су најодговорнији за спровођење програма. Можемо претпоставити да педијатри који сматрају да знају довољно о вакцинама и истовремено препоручују вакцине у складу са правилником, или чак и шире од тога, 
имају позитиван однос према имунизацији уопште и заступају је у комуникацији са родитељима и општом популацијом. Од три лекара која су се изјаснила негативно на питање о знању у вези са вакцинама, на питање да ли су потребне све вакцине које су предвиђене програмом два су одговорила негативно и навела у оба случаја вакцину против хепатитиса Б, и у једном случају и вакцину против малих богиња, заушки и рубеоле. На питање о потреби увођења нових вакцина у програм, од ова три лекара један је, поред тога што сматра да две вакцине треба избацити из програма, навео и да нове не треба уводити, док су друга два на ово питање одговорила позитивно и навела вакцину против инфекција које изазива s. pneumoniae. Разматрајући ове одговоре, можемо закључити да један од анкетираних 26 педијатара има негативан однос према имунизацији који, вероватно, почива на два разлога: недовољно знање о овој области и усвајање антивакциналних порука и ставова који се промовишу у кампањи која се са високим интензитетом води протеклих година у јавности. С друге стране, исти лекар је одговорио да препоручује све обавезне вакцине у складу са правилником, те се може претпоставити да се у свом раду свакодневно суочава са проблемом испуњавања законске обавезе (спровођење програма имунизација) која је у супротности са личним ставом да неке од вакцина нису потребне (или чак могу да буду штетне?).

Имајући у виду да су данас различити извори информација доступни свим лекарима (независно од тога колико их заиста и користе), желели смо да испитамо на који начин педијатри вреднују поузданост различитих извора. Понудили смо четири извора и тражили од испитаника да их рангирају од 1 до 4, где је 1 најмање поуздан, а 4 најпоузданији, и добили смо следеће резултате: стручна литература/ чланци су оцењени највишом просечном оценом 3,5 ; стручни састанци/предавања су на другом месту са оценом 3,1 , а на трећем месту су лични контакти/консултације са просечном оценом 2,1. Најмање поузданим се сматрају информације са интернета које су оцењене просечном оценом 1,6. Међутим, интернет као извор информација два лекара су рангирала на прво место, а један на друго. Упоређујући ове одговоре са одговорима на друга питања у њиховим упитницима (генерално позитивни ставови и пракса) може се закључити да ови лекари имају критички однос према различитим изворима информација на интернету, користе сајтове који публикују резултате научних истраживања, а интернет им пружа могућност брзог, једноставног и јефтиног добијања жељених информација.

Од 26 анкетираних, 23 лекара сматрају да су све вакцине које су предвиђене програмом имунизација у Србији и потребне, док три лекара сматрају да нису, што смо раније анализирали.

Две трећине анкетираних лекара је изјавило да поред свих обавезних вакцина препоручују и неке које нису обавезне. Познајући праксу, сматрамо да су под тим првенствено мислили на вакцину против инфекција које изазива str. pneumoniae (коњугована и полисахаридна), нарочито имајући у виду став о потреби увођења нових вакцина у програм обавезних имунизација. Једна трећина лекара своју препоруку ограничава на вакцине које су обавезне за лица одређеног узраста, не укључујући вакцине које се дају по клиничким индикацијама или нове вакцине.

Нежељена реакција после имунизације је медицински инцидент који се догодио после извршене имунизације и може се повезати са применом имунобиолошког препарата, односно било који неповољан догађај који се јави након имунизације, а који не мора нужно да буде узрочно повезан са применом вакцине. У нашем испитивању, на питање које нежељене догађаје након имунизације најчешће региструју одговорило је 20 педијатара. Углавном су наведене локалне реакције (оток, црвенило) и повишена 
температура. У по два случаја су наведени раздражљивост, оспа и интензиван плач, у једном случају повећање пљувачних жлезда након ММР вакцине. Нико од анкетираних лекара није навео озбиљније нежељене догађаје након имунизације.

Када је у питању пријављивање нежељених догађаја након имунизације, девет од 26 анкетираних лекара није никада у својој пракси пријавило нежељени догађај, од чега је шест у одговору на претходно питање навело да су у својој пракси имали само фебрилност и/или локални оток и црвенило као нежељене догађаје. Два лекара су уочене нежељене догађаје пријављивали усмено начелнику службе, пет усмено епидемиолошкој служби, а девет лекара је у својој пракси имало и нежељене догађаје које су пријављивали писменим путем епидемиологу. Један лекар је навео да је нежељени догађај пријавио тако што је дете упућено на дечје одељење.

Следећим питањем смо желели да сагледамо да ли међу педијатрима постоји мишљење о повезаности вакцина и поремећаја здравља, што се у великој мери јавља као аргумент против вакцинације у јавности. Два лекара су дала позитиван одговор, а у објашњењу су навели повезаност вакцине против великог кашља и бронхијалне хиперреактивности, односно ММР вакцине и алергије на жуманце-беланце.

Вакцинални статус никада не проверавају два педијатра (по један са примарног и секундарног нивоа здравствене заштите). Осам педијатара, од којих шест са примарног нивоа, је навело да проверу вакциналног статуса спроводи нередовно, док су остали (18) одговорили да проверу врше увек или приликом већине посета.

Редовна ревизија вакциналне картотеке је обавеза изабраних педијатара и основ за сагледавање обухвата имунизацијом за одређене вакцине и годишта. Стога смо поставили и питање како педијатри оцењују обухват обавезним имунизацијама код своје опредељене популације. Од 26 испитаних,
22 лекара су одговорила да је обухват преко 95\% за све или за већину вакцина. Један лекар је навео да сматра да је обухват испод 95\% за већину вакцина, а три да је обухват незадовољавајући за све вакцине.

Имајући у виду стварну ситуацију са обухватом, односно да се последњих година бележи све нижи проценат вакцинисане деце, сагледали смо и шта педијатри виде као главне проблеме у раду у овој области. Пошто је било омогућено да се да више од једног одговора добили смо следеће резултате:

- 85\% испитаника наводи неповерење родитеља и тражење додатних обавештења;

- 35\% је заокружило одбијање вакцинације од стране родитеља;

- 54\% сматра да су несташице вакцина један од најважнијих проблема;

- нико од анкетираних не сматра нежељене догађаје након имунизације битним проблемом у својој пракси и

- један од анкетираних педијатара наводи да се у свом раду на спровођењу имунизација не сусреће са проблемима.

Као што смо раније поменули, од анкетираних 26 педијатара, 21 сматра да је потребно увести вакцину против инфекција које изазива str. pneumoniae у програм обавезних имунизација по узрасту и један од педијатара је навео да треба увести вакцину против варичеле. Пет педијатара не сматра да програм обавезних имунизација треба допуњавати новим вакцинама.

\section{ЗАКЈЉУЧАК}

Истраживање је показало да је поверење у имунизацију код родитеља током година нарушено. За неке вакцине степен неповерења је толики да доводи до озбиљног компромитовања колективне заштите (MМР, одбијање и одлагање вакцинације).

И код педијатара смо утврдили да постоји одређени степен неповерења у вак- 
цинацију као меру, а посебно у одређене вакцине. Један од анкетираних педијатара јасно износи негативан однос према имунизацији. Пољуљано поверење међу педијатрима је у супротности најпре са научним сазнањима, али и са њиховим личним искуством јер, према резултатима истраживања, у својој каријери нису имали значајнијих нежељених догађаја у вези са имунизацијом и сведоци су одсуства болести против којих се вакцинација врши. Међутим, очигледно је да су утицаји који долазе из медија, са друштвених мрежа и од појединих медицинских ауторитета толико јаки да и код стручњака доводи до нарушавања поверења у имунизацију, односно, у медицинску науку која резултатима обимних истраживања пружа доказе ефикасности и безбедности свих медицинских поступака, па и вакцинације.

Важно је напоменути да је истраживање спроведено у децембру 2016, односно знатно пре појаве епидемије малих богиња на подручју Краљева и читаве Србије. Ова епидемија је дала прилику свима да виде последице болести и упореде их са наводним последицама вакцинације, да у већој мери размишљају о чињеницама и да упоређују поузданост различитих извора информација. Она је сигурно значајно утицала на неопредељене, неодлучне родитеље да стекну или утврде позитивне ставове и да се одазову позивима за вакцинацију деце.

\section{ЛИТЕРАТУРА}

1. Фазлић С, Марић Н. Студија знања, ставова и праксе (КАП студија) образовања и развоја током раног дјетињства у изабраним опцинама / општинама и градовима у БиХ. Финални извештај, UNICEF, Сарајево, 2014, https:// www.unicef.org/bih/ba/KAP_Report_BHS_ Dubai_lektorirano_BHS_Final.pdf.

2. Ристић М, Шегуљев 3, Петровић В, Вулековић В, Дуганџија Т. Утицај социодемографских карактеристика родитеља на обухват имунизацијом деце. Општа медицина, 2013; 19(1-2): 19-25.

3. Wheeler M, Buttenheim AM. Parental vaccine concerns, information source, and choice of alternative immunization schedules. Human Vaccines \& Immunotherapeutics. 2013; 9(8): 17821789. doi: $10.4161 / \mathrm{hv} .25959$.

4. Glanz JM, Kraus CR, Daley MF. Addressing Parental Vaccine Concerns: Engagement, Balance, and Timing. PLoS (Public Library of Science) Biology, 2015; 13(8): e1002227. https://doi.org/10.1371/ journal.pbio. 1002227 .
5. Dubé E, Gagnon D, Nickels E, Jeram S, Schuster M. Mapping vaccine hesitancy Country-specific characteristics of a global phenomenon. Vaccine. 2014; 32(49): 66496654. doi: 10.1016/j.vaccine.2014.09.039.

6. Kumar D, Chandra R, Mathur M, Samdariya S, Kapoor N. Vaccine hesitancy: understanding better to address better. Israel Journal of Health Policy Research. 2016; 5: 2. doi: 10.1186/s13584-016-0062-y.

7. Ward PR, Attwell K, Meyer SB, Rokkas $\mathrm{P}$, Leask J. Understanding the perceived logic of care by vaccine-hesitant and vaccine-refusing parents: A qualitative study in Australia. PLoS ONE 2017; 12(10): e0185955. https://doi.org/10.1371/journal. pone.0185955.

8. David EG, McIntosh JJ, Jochen HH, Ehrich and al. Vaccine hesitancy and Refusal. The Journal of Pediatrics, 2016; 175: 248-249. e1 DOI: https://doi. org/10.1016/j.jpeds.2016.06.006.

9. Ames HM, Glenton C, Lewin S. Parents' and informal caregivers' views and experiences of communication about routine childhood vaccination: a synthesis of qualitative evidence. The Cochrane 
Database of Systematic Reviews. 2017;

(2): CD011787. doi: 10.1002/14651858. CD011787.pub2.

10. Oyo-Ita A, Wiysonge CS, Oringanje C, Nwachukwu CE, Oduwole O, Meremikwu MM. Interventions for improving coverage of childhood immunisation in low- and middle-income countries. The Cochrane Database of Systematic Reviews. 2016; (7): CD008145. doi: 10.1002/14651858. CD008145.pub3.

11. Rosenthal J, Rodewald L, McCauley $\mathrm{M}$ et al. Immunization Coverage Levels
Among 19- to 35-Month-Old Children in 4 Diverse, Medically Underserved Areas of the United States. PEDIATRICS 2004; 113(4): 296-302, http:// pediatrics.aappublications.org/content/ pediatrics/113/4/e296.full.pdf.

12. Rodewald LE, Humiston SG et al. Missed Opportunities for Immunizations Easier Said Than Done, Archives of Pediatrics and Adolescent Medicine, 1996; 150(11): 1193-1200. doi: 10.1001/ archpedi.1996.02170360083014.

\section{ПРИЛОЗИ}

Графикон 5. Да ли мислите да су вакиине ефикасне у спречавању болести?

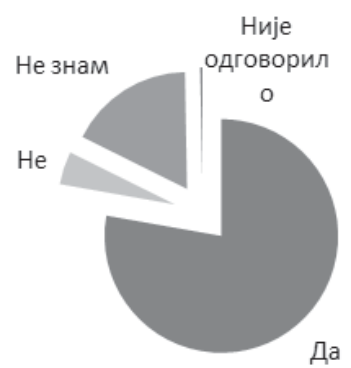

Графикон 6. Да ли можете да наведете пет болести против којих је ваше дете вакцинисано или треба да се вакцинише?

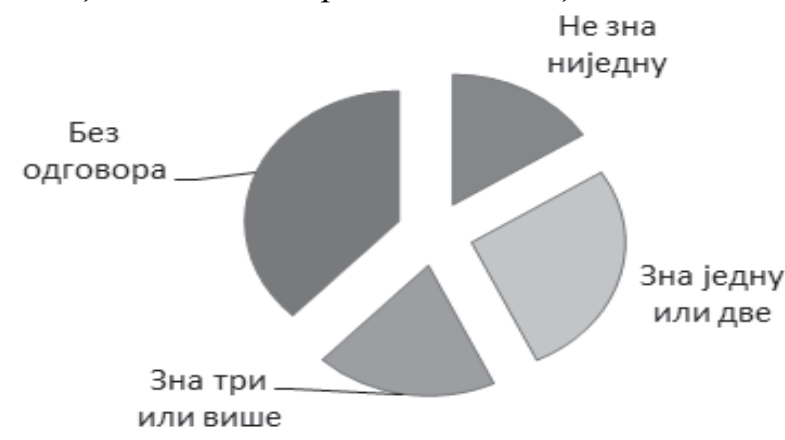

Графикон 7. Да ли се у Србији даје више или мање вакиина у дечјем узрасту него у другим европским земљама?

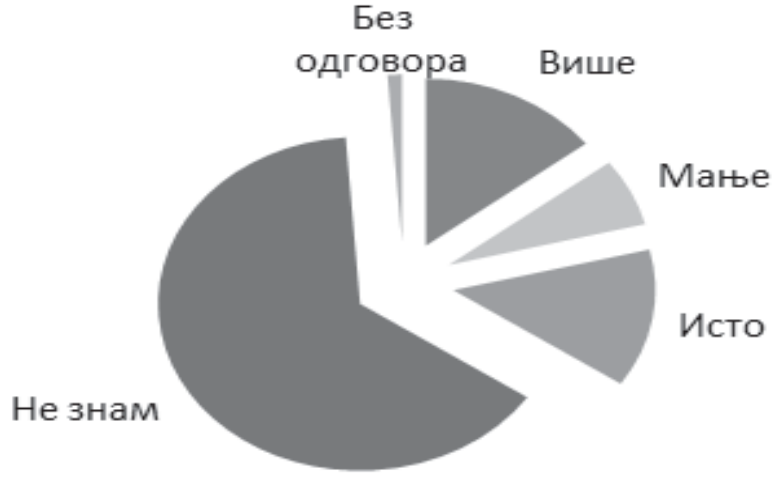

Графикон 8. Да ли сматрате да као родитељ/ старатељь имате довољно информачија о вакиинацији?

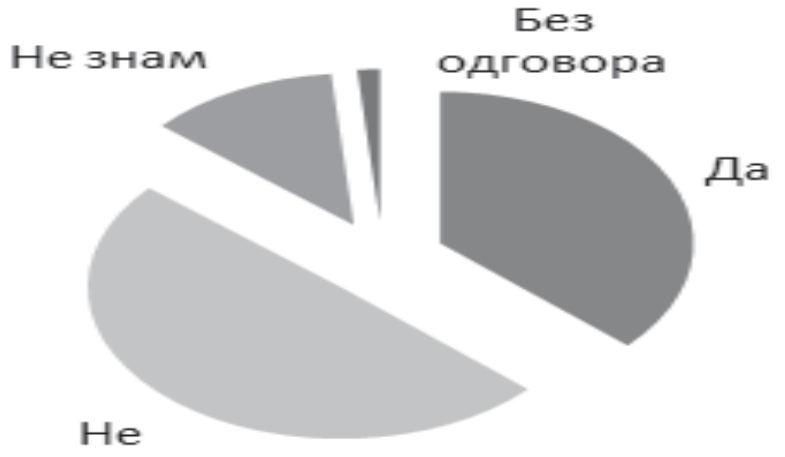


Графикон 9. Најчешће коришћени извори информација о вакциначији.
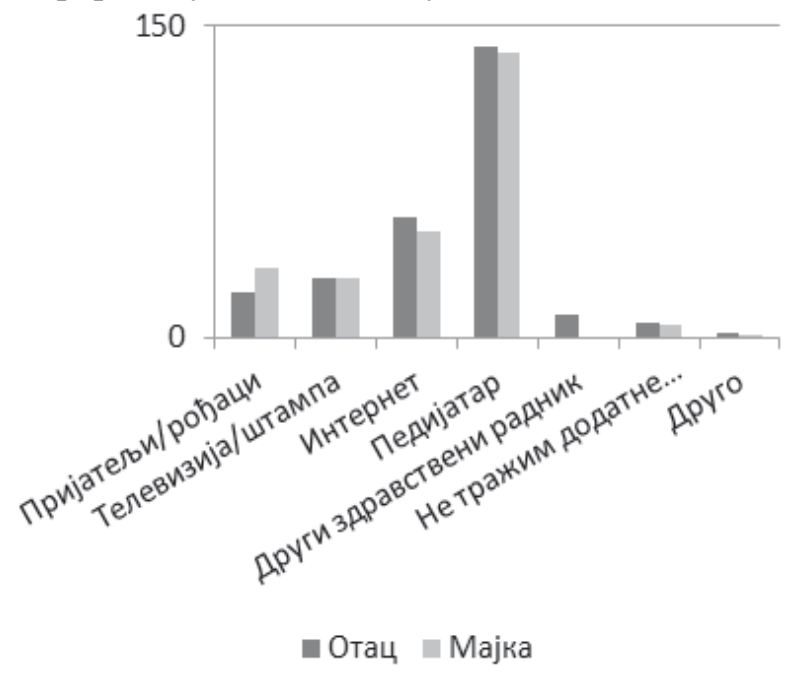

Графикон 10. Оиена поузданости (1-5) различитих извора информачија.

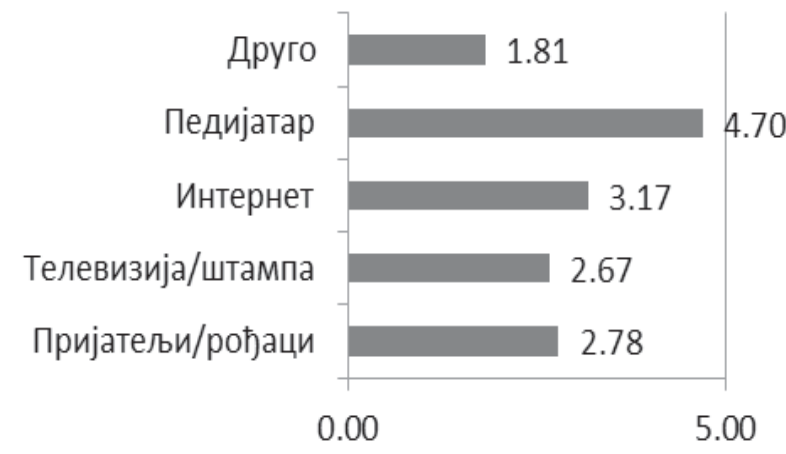

Графикон 11. Да ли ћете наставити да водите своје дете на вакцинацију?

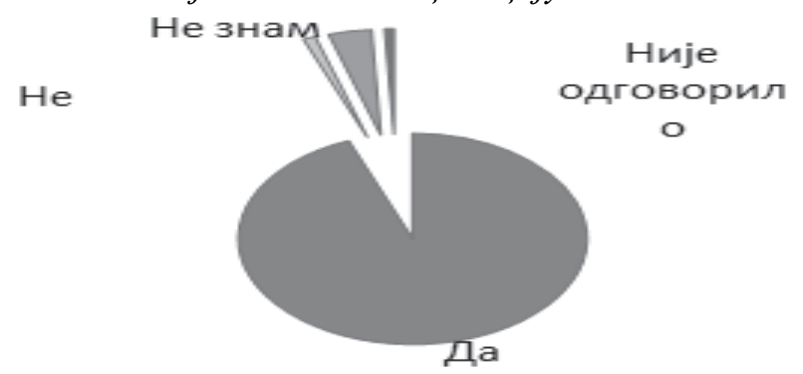

Графикон 12. Да ли су разговори о вакцинацији деце део уобичајених разговора са пријатељима/рођачима?

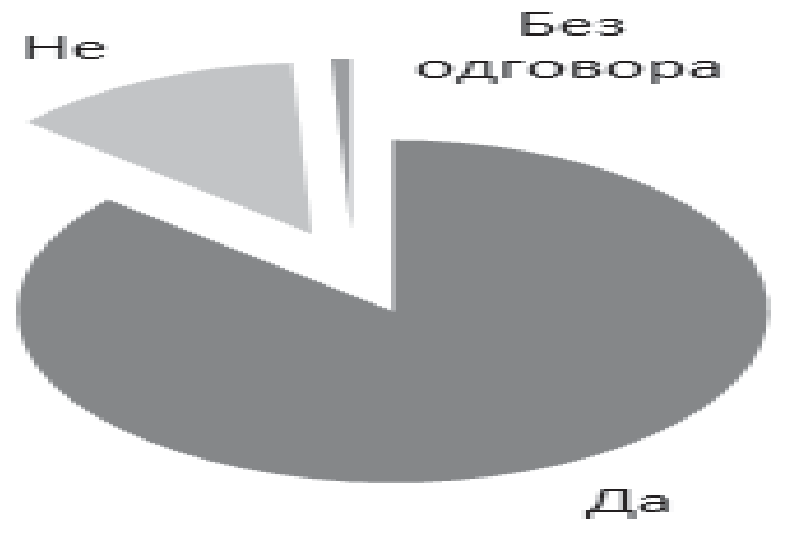

Графикон 13. Да ли блиским пријатељима препоручујете да вакиинишу своју деиу?

$\mathrm{He}$

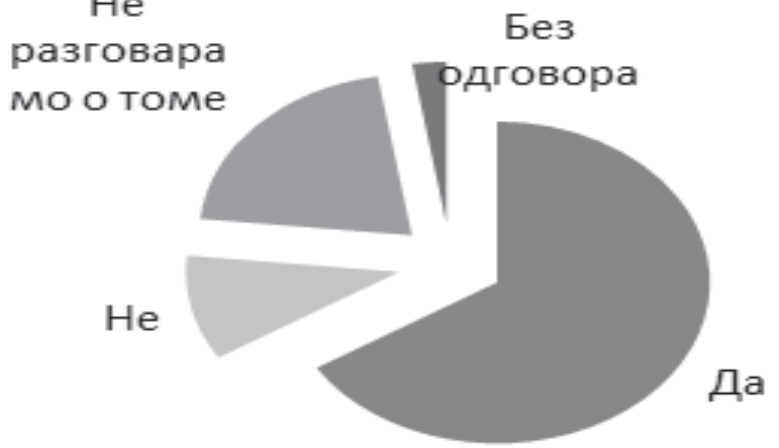

Графикон 14. Да ли мислите да неке од вакцина могу нашкодити здрављу детета?

\section{Без}

одговора

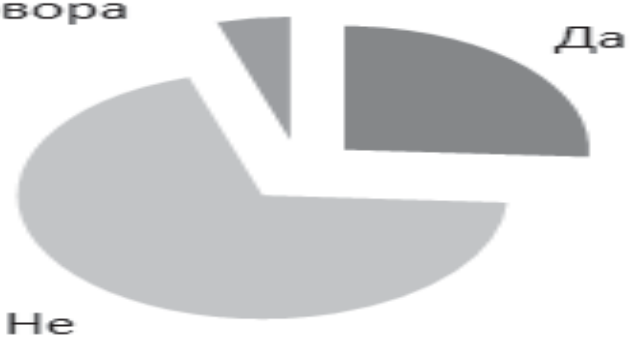

Графикон 15. Дали мислите да су неке вакиине непотребне?

\section{Be:}

Cम,

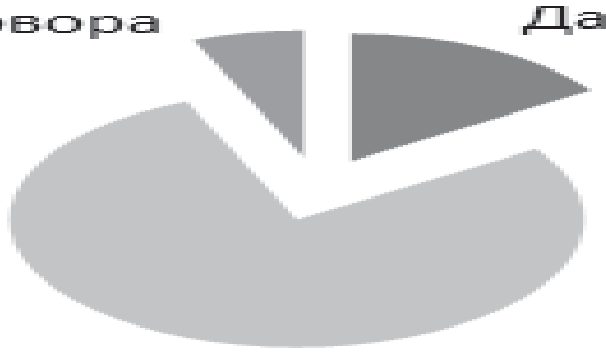


Графикон 16. Да ли верујете да су вакиине испитане и поуздане?

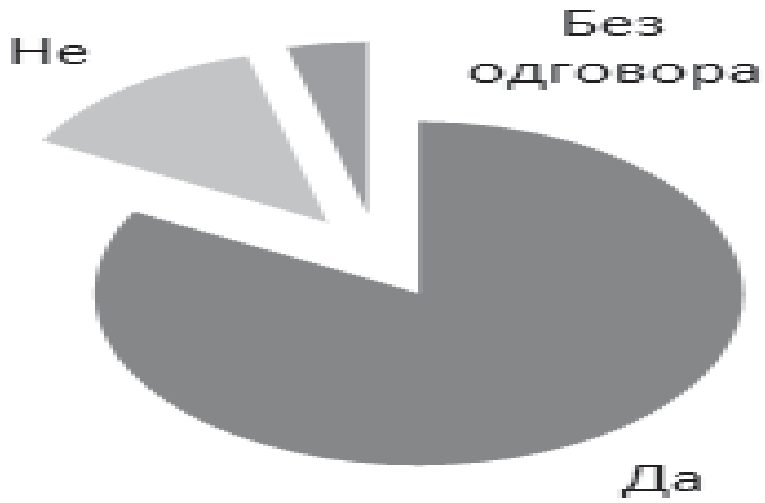

Графикон 17. Да ли мислите да постоји разлика између вакцина произведених у Србији и оних које се увозе?

\section{Без}

\section{одговора}

$\mathrm{He}$
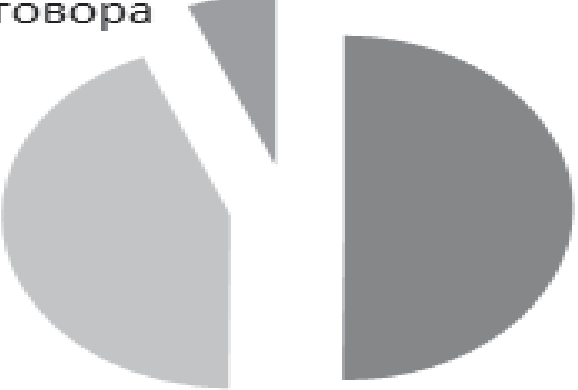

Да

Табела 3. Које вакичине сматрате непотребним?

\begin{tabular}{|c|l|c|}
\hline $\begin{array}{l}\text { Редни } \\
\text { број }\end{array}$ & \multicolumn{1}{|c|}{ Вакцина } & $\begin{array}{l}\text { Број } \\
\text { одговора }\end{array}$ \\
\hline 0 & 1 & 2 \\
\hline 1 & Вакцина против хепатитиса Б & 4 \\
\hline 2 & ММР & 10 \\
\hline 3 & ВСG & 1 \\
\hline 4 & Све ревакцине & 1 \\
\hline 5 & Не знам тачно & 1 \\
\hline
\end{tabular}

Графикон 18. Начин добијања обавештења о заказаној вакцинащији деце.

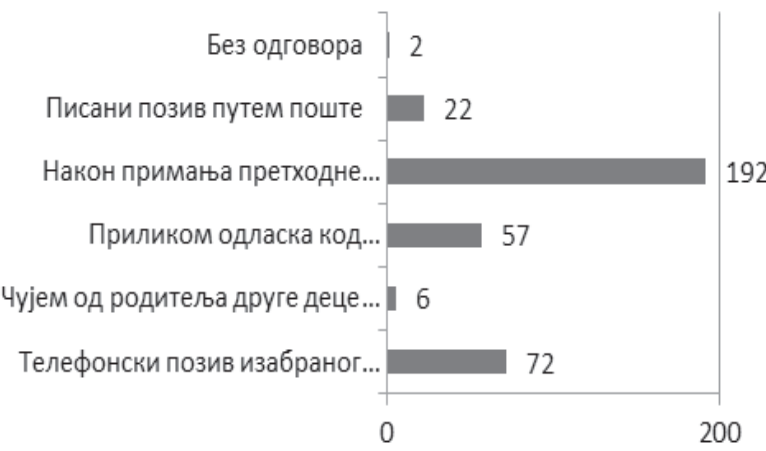

Графикон 19. Да ли тражите од педијатра додатна обавештења о вакиинама?

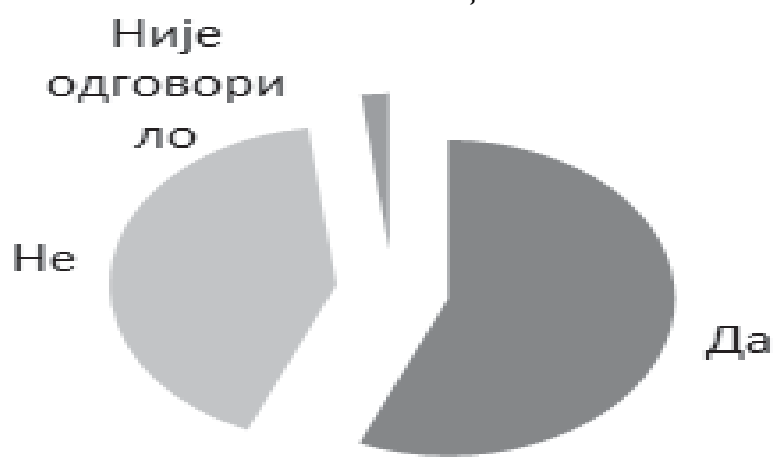

Графикон 20. Да ли тражите од педијатра додатна обавештења о другим лековима прописаним вашем детету?

$$
\text { Није }
$$

\section{одговорил}

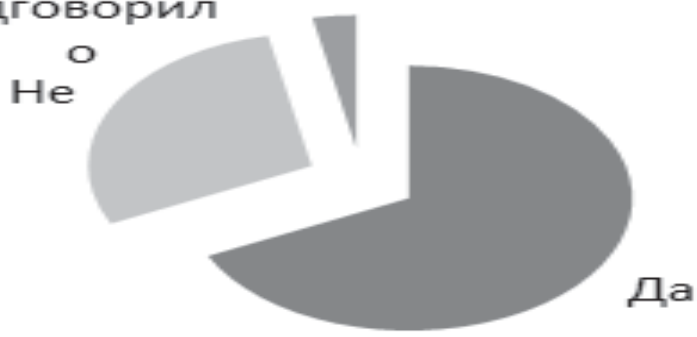

Графикон 21. Да ли сте некад одбили да свом детету дајете лек који је прописао neдujamap?

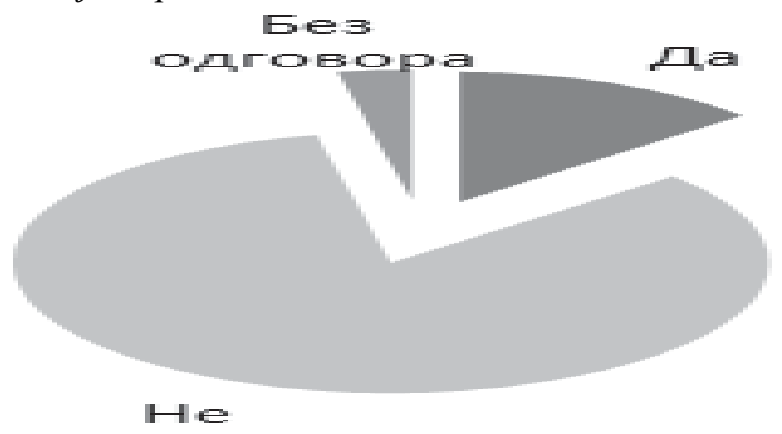

Графикон 22. Да ли се дешавало да ваше дете не прими вакцину у заказаном термину, односно да се вакциннација одложи?

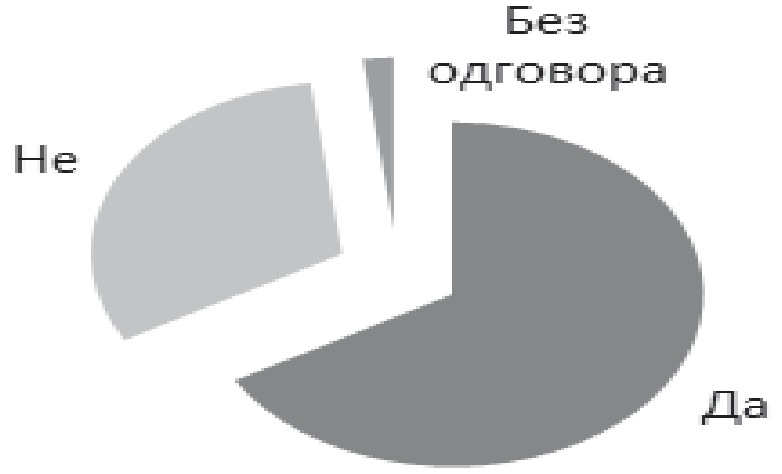


Графикон 23. Разлози одлагања вакциинаиије.

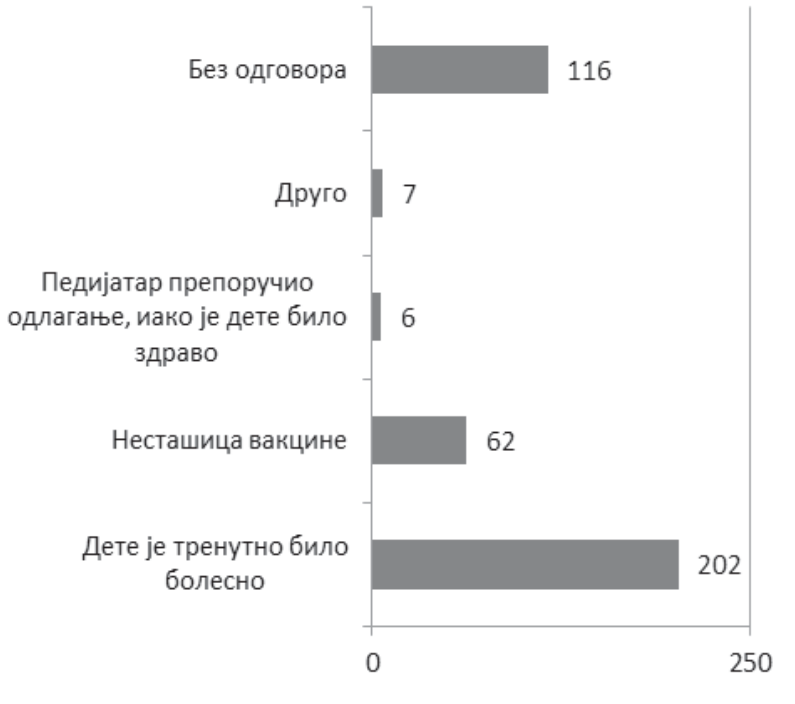

Графикон 24. Због чега ваше дете није потпуно вакцинисано свим предвиђеним вакцинама?

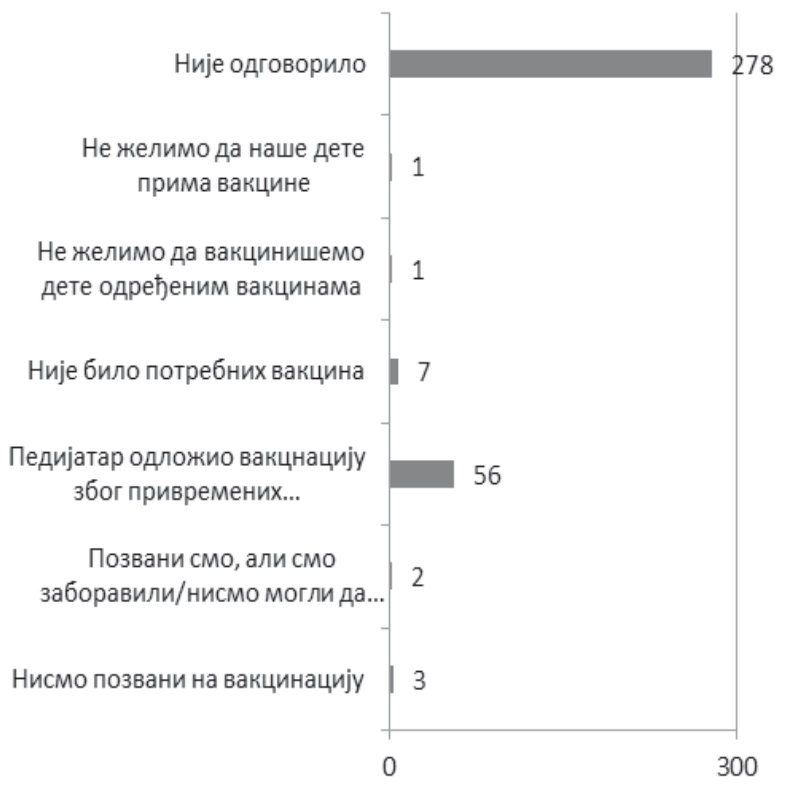

Контакт: Др Верица Ђукић, Центар за превенцију и контролу болести, Завод за јавно здравље Краљево, Србија. 